opportunity to abserve this handsome bird frequently. In addition, I have hunted this bird almost annually for the last 15 years, and therefore have had many opportunities to observe morphological characteristics close at hand.

The area in which this bird was sighted is largely short-grass prairie, sparsely interspersed with small bluffs of poplars (Populus spp.). According to March (1971), the Band-tailed Pigeon is locally common in southwestern British Columbia and is confined to that area west of the Cascade Mountains.

This $j_{3}$ apparently the third sighting of a Band-tailed Pigeon in Alberta during recent years. A specimen was obtained on July 27, 1967, at Leduc, Alberta, by Mr. Harvey Burns (Spalding and Hampson, 1969). A second sighting was recorded from the foothills country west of Calgary on August 16, 1968 (Wilson, 1968). The status of this species in Alberta is as yet undetermined.

\section{LITERATURE CITED}

Godfrey, W. E. 1966. The birds of Canada. Nat. Mus. Bull. No. 203 - Biol. Ser. No. 73, $428 \mathrm{pp}$.

March, G. L. 1971. The biology of the Bandtailed Pigeon (Columba fasciata) in British Columbia. Ph.D. Thesis, Simon Fraser University.

Peterson, R. T. 1961. A field guide to western birds. Houghton Mifflin. Co., Boston.

Spalding, D. A. E., and M. J. Hampson, 1969. First Alberta record of the Band-tailed Pigeon. Can. Field-Nat. $83: 282-284$

Wilson, M. 1968. New sighting of Band-tailed Pigeon in Alberta. Blue Jay 26:181.

\title{
VARIATION IN DENSITY OF BREEDING DUCKS ACROSS THE ASPEN PARKLANDS AND GRASSLANDS OF CANADA
}

\author{
by Kees Vermeer, Canadian Wildlife Service, Edmonton, Alberta
}

The aspen parklands and grasslands of the Prairie Provinces of Canada contain potholes, marshes and lakes and constitute the major breeding ground for most game duck species in North America. Excluding scoters, eiders, mergansers and oldsquaws, Crissey (1969) estimated that during 1955-64 an average of 47 percent of the North American duck population and 61 percent of the Canadian duck population utilized this region for breeding.

This region has been divided into 10 survey strata (Fig. 1). Table 1 shows the biotic zone and area of each stratum. Stratum 25 is an exception to the other nine strata in that it is in the boreal forest. However, much of the boreal forest has been cleared in this stratum, making it similar for waterfowl observing to those encountered in adjacent parkland. For this reason it has been included here.

In May, surveys are carried out within each stratum to determine the status of waterfowl breeding popula- tions. Average numbers of breeding pairs per square mile during 1960-69 for the 10 survey strata are given for Mallard (Anas platyrhynchos), Pintail (Anas acuta), Gadwall (Anas strepera), American Widgeon (Mareca americana), Shoveler, (Spatula clypeata), Blue - winged Teal (Anas discors), Green-winged Teal (Anas carolinensis), Redhead (Aythya americana), Canvasback (Aythya valisineria), and Lesser Scaup (Aythya affinis).

The purpose of this study was to determine for each species the breeding pair density in each stratum and the preference for a biotic zone.

\section{Methods}

The annual breeding pair surveys have been conducted and published by the U.S. Bureau of Sport Fisheries and Wildlife. Detailed description of the methods used in the waterfowl breeding pair survey is given in the United States Fish and Wildlife Service manual: Standard Procedures for 


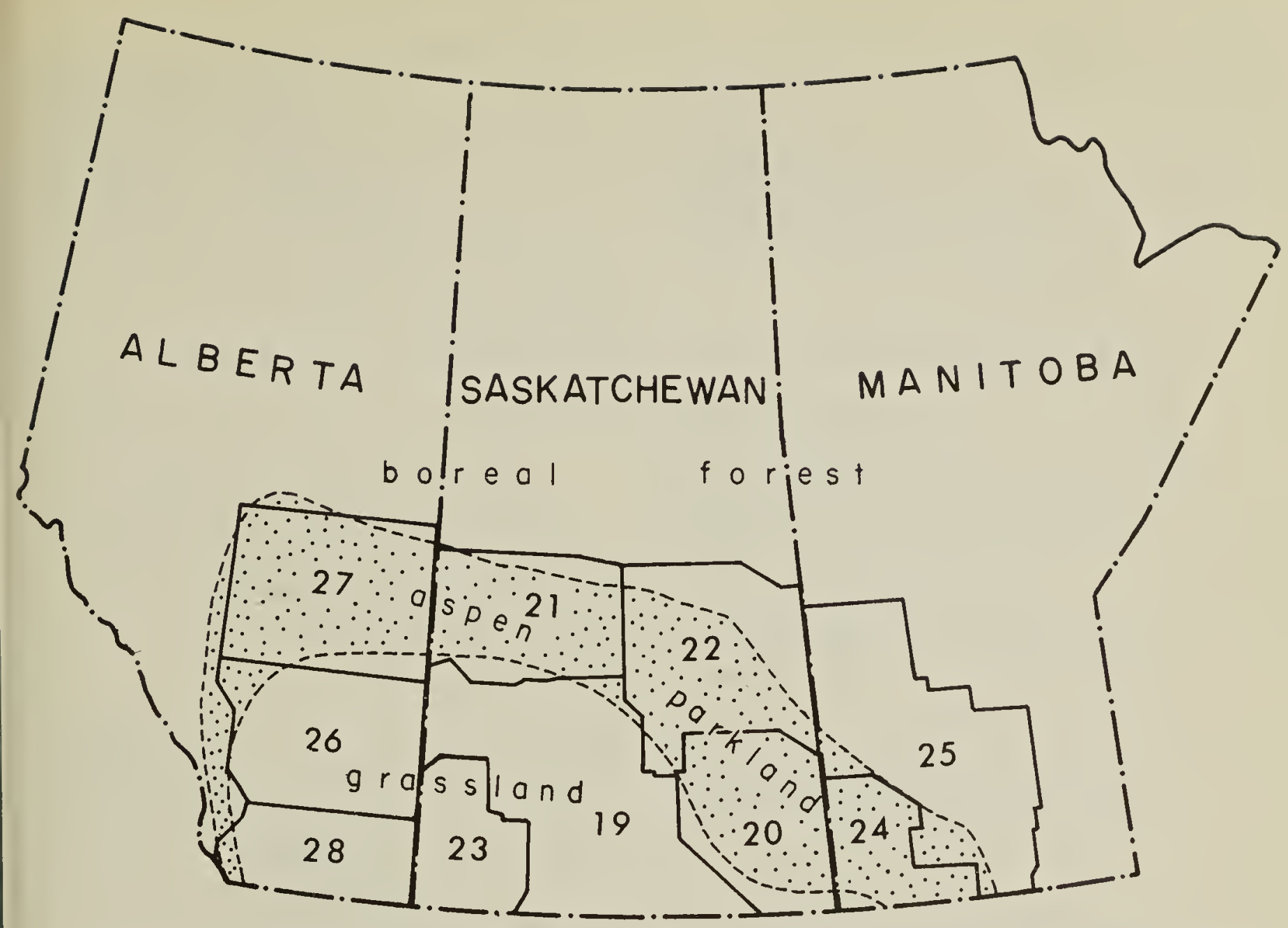

Fig. 1. Geographic locations of waterfowl survey strata in the aspen parkland and grassland.

Waterfowl Population and Habitat Surveys (1969). The waterfowl breeding population indices were taken from the United States Fish and Wildlife Service Waterfowl Status Reports (1960-69).

Population index $=$ Aerial count of breeding ducks

$\times$ Stratum area

Surveyed area

Visibility rate $=$ Aerial count ground count

of air: ground comparison transect

Visibility rates are used to adjust breeding population indices as there are discrepancies between aerial and ground counts. Air:ground comparison transect survey techniques were not perfected until 1961. As no visibility rates were available for 1960 , averages of 1961-1969 rates were used for that year.

To obtain figures on average breeding pairs per square mile for the period 1960-69: 1) breeding population indices were divided by visibility rates to obtain adjusted breeding populations for each species by stratum and year; 2) the adjusted breeding populations were divided by the area

Table 1. Biotic zone and area of Survey Strata

\begin{tabular}{lcc}
\hline Biotic zone & $\begin{array}{c}\text { Stratum } \\
\text { number }\end{array}$ & $\begin{array}{c}\text { Area } \\
\text { (square miles) }\end{array}$ \\
\hline Boreal forest & 25 & $28,600(1960-69)$ \\
Boreal forest/ & 22 & $33,720(1960-66)$ \\
parkland & & $38,890(1967-69)$ \\
Aspen parkland & 24 & $10,370(1960-69)$ \\
Aspen parkland & 20 & $14,600(1960-69)$ \\
Aspen parkland & 21 & $16,800(1960-66)$ \\
& & $17,880(1967-69)$ \\
Aspen parkland & 27 & $26,100(1960-66)$ \\
& & $26,090(1967-69)$ \\
Grassland & 19 & $37,630(1960-69)$ \\
Grassland & 23 & $11,290(1960-69)$ \\
Grassland & 26 & $22,090(1960-66)$ \\
& & $24,610(1967-69)$ \\
Grassland & 28 & $16,110(1960-66)$ \\
& & $13,240(1967-69)$ \\
Strata combined & & $217,310(1960-66)$ \\
& & $218,200(1967-69)$
\end{tabular}




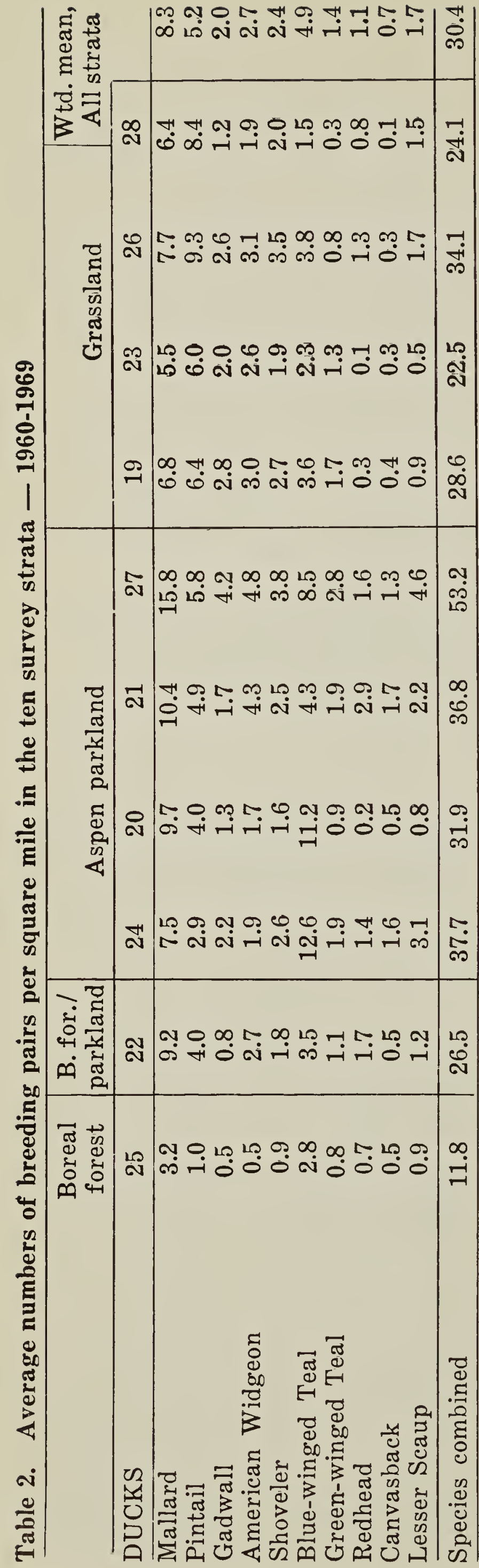

of each stratum to obtain numbers of breeders per square mile; 3 ) the resulting figures were divided by two to obtain breeding pairs per square mile; 4) the breeding pairs per square mile were averaged for the 10-year period.

Breeding pair densities of ducks unadjusted for visibility rates in the aspen parklands and grasslands were compared with those of the boreal forest north of that region.

\section{Results and Discussion}

Average breeding pair densities during 1960-69 for 10 species of ducks are shown (Table 2) for each of the 10 strata. The densities for seven dabbling duck species are illustrated in Fig. 2 and for three diving duck species in Fig. 3.

Mallards, with the highest density over the entire region, averaged eight breeding pairs per square mile (Table 2). Pintails and Blue-winged Teal had the second highest density. For the 10 species the average density was about 30 breeding pairs per square mile.

Stratum 27, in the parklands of Alberta, had the highest density for the Mallard, Gadwall, American Widgeon, Shoveler, Green-winged Teal, and Lesser Scaup. Pintail densities were highest in Strata 26 and 28 in the Alberta grasslands. Blue-winged Teal densities were highest in Strata 20 and

Table 3. Comparison of breeding pair densities, unadjusted for visibility rates, between the parkland-grassland region and the boreal forest to its north for the period 19611970.

\begin{tabular}{lcc}
\hline Species & $\begin{array}{c}\text { Aspen parklands } \\
\text { and grasslands }\end{array}$ & $\begin{array}{c}\text { Boreal } \\
\text { forest }\end{array}$ \\
\hline Mallard & 3.8 & 0.6 \\
Pintail & 1.9 & 0.1 \\
Gadwall & 0.6 & 0.0 \\
American Widgeon & 0.7 & 0.2 \\
Blue-winged Teal & 0.6 & 0.1 \\
Green-winged Teal & 0.2 & 0.1 \\
Shoveler & 0.9 & 0.1 \\
Redhead & 0.2 & 0.0 \\
Canvasback & 0.4 & 0.1 \\
Lesser Scaup & 0.9 & 1.4
\end{tabular}




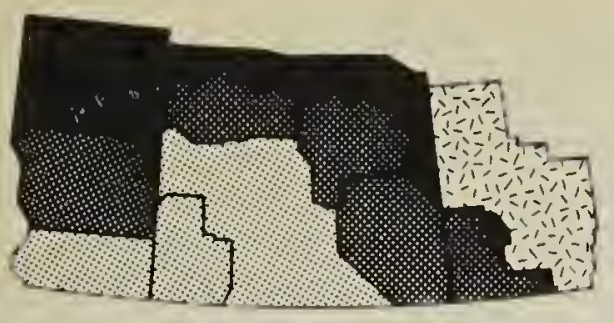

Mallard

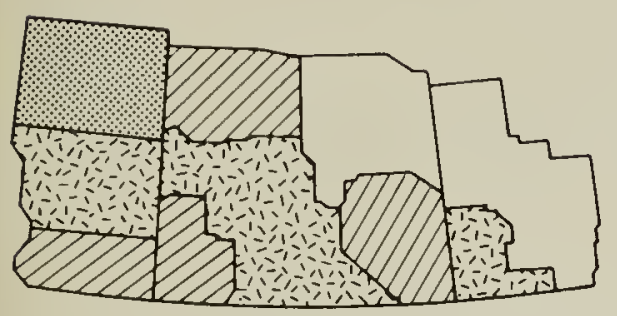

- Gadwall

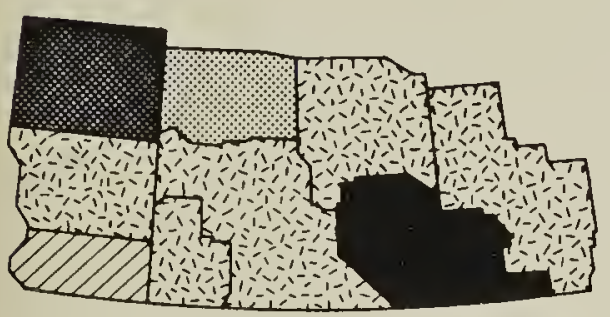

Blue-winged Teal

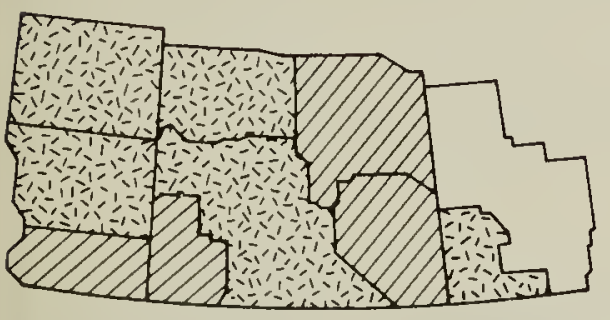

Shoveler
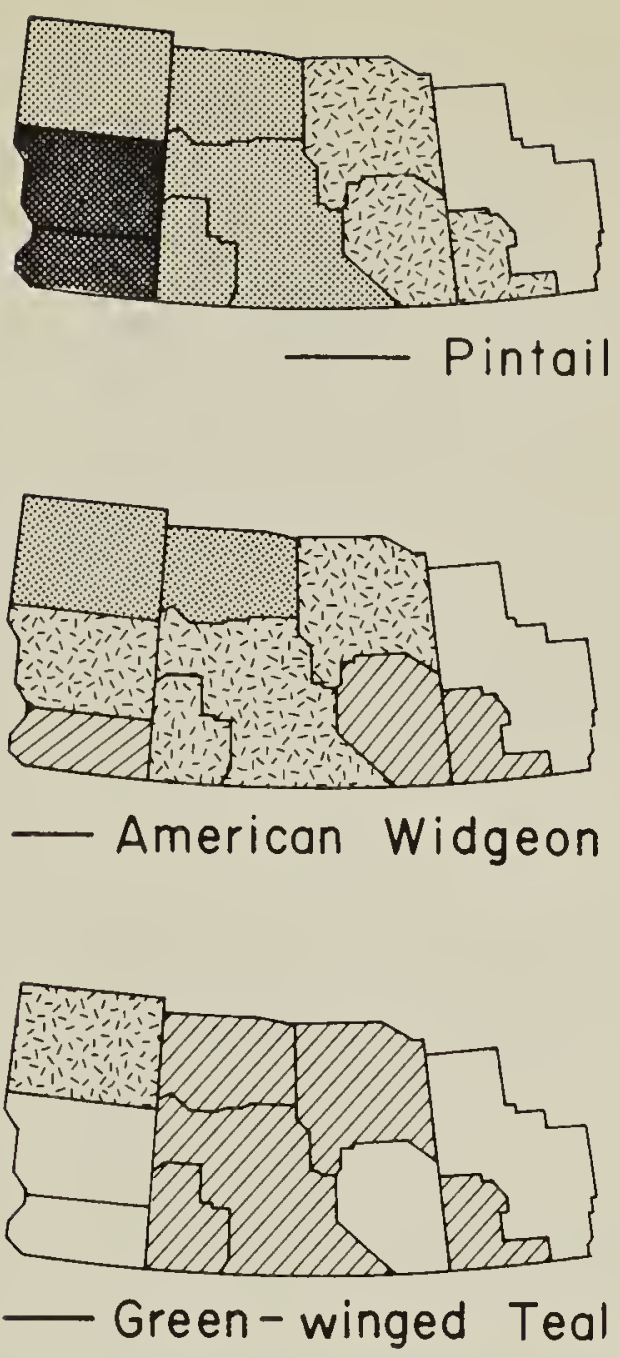

PAIRS PER SQUARE MILE
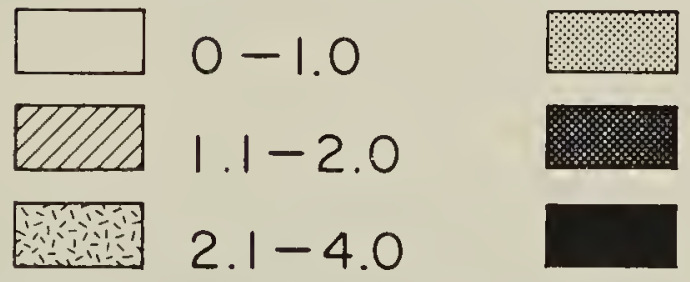

$4.1-7.0$

$7.1-11.0$

$11.1-16.0$

Fig 2. Breeding pair densities of seven species of dabbling ducks in the aspen parkland and grassland.

24 , which may be related to the fact that those strata had the highest aver. age number of ponds in May of 19601969 of all strata. There was a highly significant correlation between Bluewinged Teal and May pond densities $(r=0.818)$. No positive significant correlation was found for the other species. The obtained breeding pair density for a species within a stratum probably depends on the interaction of many factors within that stratum, one of which is May pond density. May pond density may be the most importantfactor influencing Blue-winged Teal densities but not those of other ducks. Densities of Mallard, Redhead,
Canvasback and Lesser Scaup in different strata in relation to the vegetation of strata suggests some preference for aspen parkland.

Unadjusted breeding pair densities for the 10 survey strata in the aspen parklands and grasslands are compared in Table 3 with those of survey strata in the boreal forest of northern Alberta, northern Saskatchewan, northern Manitoba, northeastern British Columbia and the Northwest Territories. As visibility correction factors for areas north of the aspen parklands and grasslands are based upon small samples and are of questionable accuracy, the densities can 

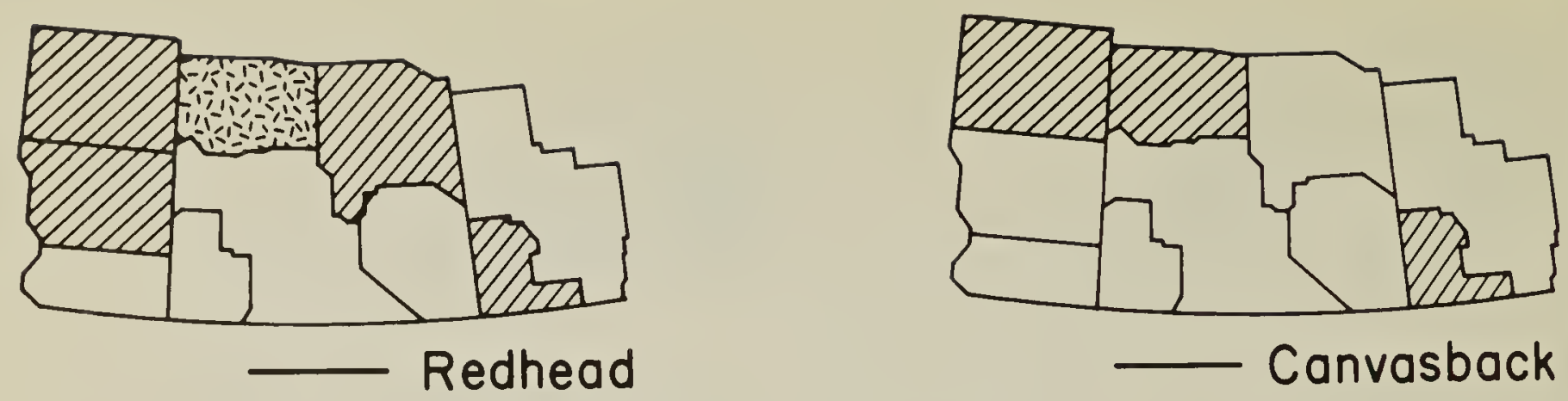

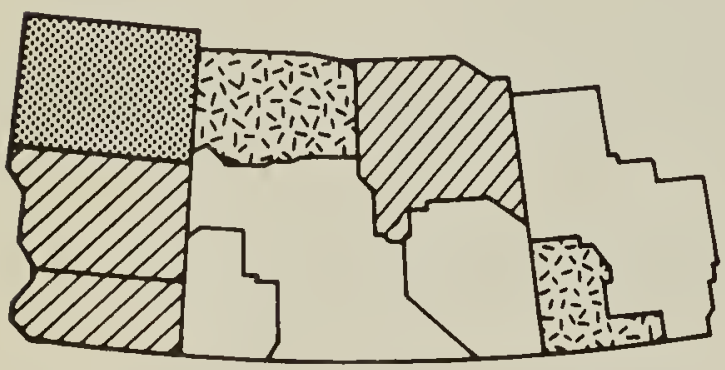

Lesser Scaup
PAIRS PER SQUARE MILE

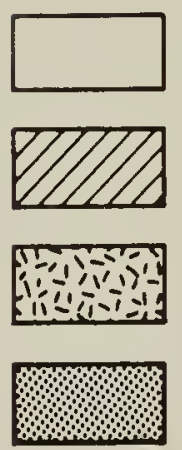

Fig. 3. Breeding pair densities of three species of diving ducks in the aspen parkland and grassland.

only be used on a comparative basis for the parkland-grassland region and the boreal forest to its north. It can be seen that only the Lesser Scaup has a higher density in the boreal forest. That Lesser Scaup are the most numerous breeding duck in the boreal forest is also supported by observations in Alberta by Vermeer (1970), in Saskatchewan by Townsend (1966) and in the Northwest Territories by Murdy et al. (1970). A small fraction of the Lesser Scaup density in the boreal forest is probably constituted by Greater Scaup (Aythya marila). Murdy et al. (1970) found that Greater Scaup in the Yellowknife area appeared to be chiefly confined to islands in Great Slave Lake. Vermeer et al. (in press) also found that Greater Scaup was the most common breeder on an island in northern Lake Winnipeg, which is 300 miles south of the breeding boundary for this species as indicated by Godfrey (1966).

\section{Acknowledgments}

The author expresses appreciation to his wife Rebecca for reviewing the manuscript; to R. J. Isbister, for his assistance in preparing figures and tables; and to R. C. Hanson and M. Smith for providing visibility rates for survey strata in Saskatchewan and Manitoba for 1967.

\section{LITERATURE CITED}

Crissey, W. J. 1969. Prairie potholes from a continental viewpoint. Can. Wildl. Serv. Rept. Ser. 6 (Saskatoon Wetlands Seminar) : 161-171.

Godfrey, W. E. 1966. The birds of Canada. Bull. 203, Biol. Ser. 73, Nat. Mus. of Can. $428 \mathrm{pp}$.

Murdy, H. W., D. L. Trauger, and H. K. Nelson. 1970. Waterfowl research on the Yellowknife study area, 1961-1970. Trans. 34 th Fed. Prov. Wildl. Conf. Yellowknife, 1970.

Townsend G. H. 1966. A study of waterfowl nesting on the Saskatchewan River Delta. Can. Field-Nat., $80: 74-88$.

U.S. Fish and Wildlife Service. 1960-1970. Waterfowl status reports, U.S. Fish and Wildl. Serv. Spec. Sci. Repts. 51, 61, 68, $75,86,90,99,111,122,128$ and 138.

U.S. Fish and Wildlife Service. 1969. Standard procedures for waterfowl population and habitat surveys-the prairies. U.S. Fish and Wildl. Serv. Manual. 68 pp.

Vermeer, K. 1970. Some aspects of the nesting of ducks on islands in Lake Newell, Alberta. J. Wildl. Mgmt., $34: 126-129$.

Vermeer, K., D. R. M. Hatch, and J. A. Windsor. Greater Scaup is common breeder on northern Lake Winnipeg. Can. Field= Nat. In press. 